\title{
Research and Development of Accelerator Based Neutron Sources
}

Yoshiaki Kiyanagi

Graduate School of Engineering, Nagoya University

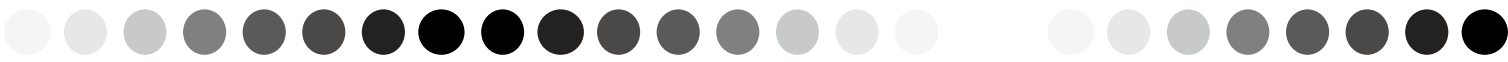

\begin{abstract}
Full-fledged neutronic study on neutron sources at an accelerator driven neutron source was started at Hokkaido University in Japan. The methane cold moderator was firstly developed and then a quasi-elastic spectrometer was constructed. They were transferred to KEK neutron source, KENS. After then, by using the Hokkaido University neutron source (HUNS), we developed for J-PARC a coupled hydrogen moderator that is the most efficient cold moderator. The pulsed neutron imaging is one of unique experiments. Owing to a compact neutron source with the cooperative use of the large facilities the pulsed neutron imaging has been developed and expanding its application fields, which lead to the imaging instrument RADEN.

Keywords: coupled neutron moderator, neutron device, pulsed neutron imaging, Bragg edge transmission
\end{abstract}

\section{1. はじめに}

私は学部 4 年の時から四十数年に亘る長い間, 中性子だけをテーマに研究してきました.今回, 学会賞を頂けたことは，これまで努力してきた方 向が間違って居なかったことの証左でもあり，大 変有難く思っています.

大竹学会賞選考委員長から会長としての私へ, 選考結果の報告書が送られてきました。その中に 私の名前があり，受けて良いものかどうか何日か 考えました。規則を再確認するために改めて学会 賞規定について読み返し，特別な賞を授与する場 合は会長が推薦することになっていますが，その ほかの賞については，会長が関与することはあり ません，選考結果を会長が受け，それを評議員会 に諮って承認を得るという手順でした。選考委員 会が議論を尽くして出した結論であれば，それを 尊重すべきという考えに至り，評議員会の議に付 しました．今の規約は，すべての学会員が受賞で きるように門戸を開けています。

さて，受賞内容について話を進めさせて頂きま す. 北大の加速器中性子源 (HUNS) は 1973 年に 完成しました。その頃は，故井上和彦教授が冷中 性子源開発に力を入れていて，現在でも最高性能 と言われている20K 固体メタン冷中性子源を開発 しました[1].さらに, 準弾性散乱装置 LANDAM[2] を作り，回転拡散の実験や散乱モデルの開発を楽 しみました。これらの装置は，その後，KEK中性 子源，KENS に移植されました。 KENS では，最 初, He-4UCN 源のためのスーパーリークを利用し
た純 He-4 の作製に従事しました。さらに，準弾 性・非弾性散乱装置である LAM 型分光器 3 台を 製作しましたが，これの大変だった所は， S/N 比 を高くすることで, 電気ノイズを極限まで下げる， 遮蔽を効果的に行うことのために半徹の日々を過 ごしました。これがデータの質の向上に大きく寄 与しました[3]. その後, 次期大型パルス中性子源 用減速材開発に研究の軸足を移すことになりまし た。それに少し遅れてパルス中性子イメージング 法の開発[4], 検出器や集束デバイスなどの開発を 行いました。磁場による中性子集束は名大の清水 教授が，まだ理研にいた時代に KENS で始めたも のですが，北大でのそれまでの経験をバックに， 世界で初めて観測に成功しました[5]. これが中性 子デバイス開発の大きな動きにつながりました。 その後, 核データ測定の JST プロジェクトの代表 を務め，J-PARC/MLF に中性子核反応測定装置 ANNRI を建設しました[6]. 世界最高強度の装置 で，これまでデータがなかったマイナーアクチナ イドの測定などで威力を発揮しています [7].

以下に，本受賞に関連した主な研究である J-PARC 用中性子源の開発，および最近の研究で, BL22 の RADEN（螺鈿）建設につながったパルス 中性子イメージングについて説明させて頂きます.

\section{2. 冷中性子減速材の開発}

KENS が完成してすぐに次期中性子源計画 GEMINI が立ち上がりました。これはISIS 程度の パワーの計画でしたが，その後，大型ハドロン計 
画 N-Arena として発展していき, $0.5 \mathrm{MW}$ の中性子 源となりました。 それと, 当時の原子力研究所の 中性子科学研究センターの $5 \mathrm{MW}$ 計画が一緒にな って, 今の大型陽子加速器施設 J-PARC $の 1 \mathrm{MW}$ 中 性子源となりました。固体メタンは放射線損傷の ために, KENS の数 $\mathrm{kW}$ の加速器パワーでさえ 2-3 日でガスを交換していました。従って，J-PARC では使えない訳で，強度がメタンの数分の 1 の液 体水素減速材だけが，事実上唯一の候補で，その 強度をいかに増やすかが大きな課題でした。

Fig. 1 に中性子減速材集合体を示します[9].こ れまでは，右側の図にあるような，非結合型減速 材が使われていました。 非結合型 (Decoupled) で はデカップラーという熱中性子吸収材を減速材と 反射体の間に挿入し，熱中性子が減速材と反射体 の間を行き来するのを防ぎます. $\mathrm{MeV}$ 領域で発生 する中性子は，反射体で熱中性子まで減速・熱化

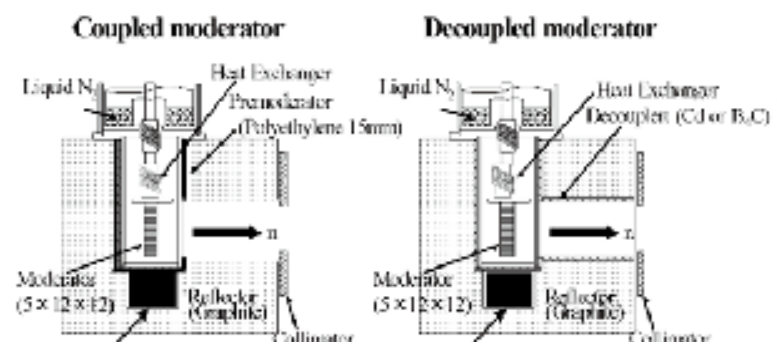

Fig. 1 Coupled (left) and decoupled (right) moderator systems.

するには msec オーダーの減速時間が掛かります. この減速時間は飛行時間法のエネルギー分解能を 悪化させるため，デカップラーを挿入して，熱中 性子を吸収する訳です。このデカップラーを外し たのが左側の結合型（Coupled）です.デカップラ 一を外すことによって強度が増えることは知られ ていたことでしたが，上に述べた理由で，それま で詳細な測定が行われていませんでした。液体水 素減速材について，これをやってみようと渡邊先 生と議論し，HUNS で実施しました，それまでの 常識に挑戦してみようと言うことです。測定した 非結合型固体メタンと結合型，非結合型の液体水 素減速材の中性子放出時間分布を Fig. 2 に示しま す[8]. 確かに, 結合型の放出時間分布は広がって

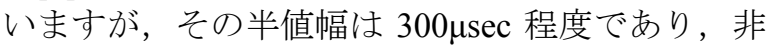
結合型の 2 倍程度でした。また，パルスピークは ほぼ固体メタンと同じであり, 非結合型水素と比 較すると倍位の強度になっています。積分強度は 固体メタンの 2 倍位，非結合型水素の 6 倍位にな っています.この特性は十分使用できるものです.

しかし，更にパルス幅を短くできないかと思っ て，シミュレーション計算でトライしたのがパラ 水素です。これまでの実験では，水素のスピンが 反平行のパラと平行のオルソが $25 \%$ と $75 \%$ で入っ ているノーマル水素を液化してすぐのもの（おお よそパラ水素 35\%）を使用していました．水素分 子の安定状態はパラなので，低温ではオルソ水素 がパラ水素にゆっくりと変換していきます，冷中 性子領域ではオルソ水素に中性子がぶつかってパ

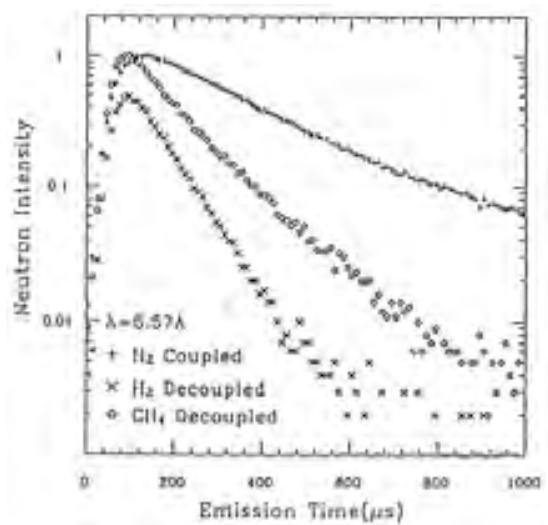

Fig. 2 Neutron emission time distributions from three moderators.

ラに変換する散乱が主として起きます。これによ って中性子は $15 \mathrm{meV}$ のエネルギーを貴うため, 冷 中性子源の特性を悪化させる要因になると考えら れます。計算では, パラ水素にすると放出時間分 布が狭くなること, また, 結合型では厚くするこ とによって, 放出時間の減衰時間は余り変わらな いのに積分強度が増えるという非常に都合の良い 特性があることが分かりました[9]. これを実験的 に検証しようということで，触媒を選択し，オル ソハパラ濃度比測定装置を自前で作り, それらを組 上げてオルソ $\rightarrow$ パラ変換装置を作りました。 パラ 濃度を変化させて中性子スペクトルと中性子放出 時間分布測定を行いました. Fig. 3 にパラ水素濃 度が 35\%と 99\%のときの放出時間分布を示します [10]. 上が線形プロットで，下がセミログプロッ 卜です。パラ水素濃度が高くなると, 減衰が早く なっていて，ピーク強度が高くなっているのが分 かります、特に，非結合型では，非常にシャープ になっています。 SuperHRPD の分解能が高いの は，この特性に依っています。このようにパラ水

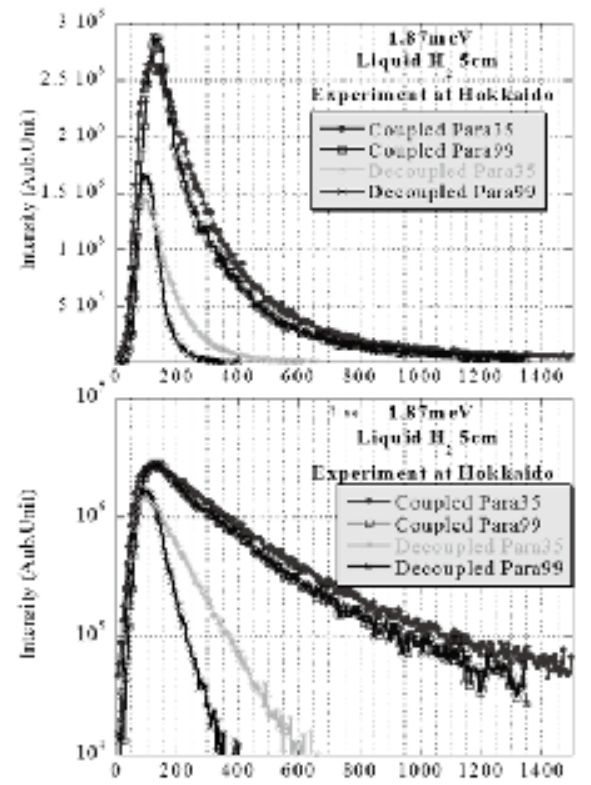

Fig. 3 Emission time distributions at $35 \%$ and $99 \%$ para hydrogen concentration. 
素にすることにメリットがあることが分かりまし たが，実際の強中性子場でパラ水素濃度が維持さ れるのかが，当時，アメリカの SNS や J-PARC の 中性子源グループで問題となっていました。 Los Alamos の中性子源は加速器パワーが $80 \mathrm{~kW}$ と J-PARC と比べたら大分弱いですが, パラ変換がさ れていなかったので，ノーマル水素から作製した 水素中性子源が時間とともにどう変わって行くか を測定できる唯一の場所でした。それで，Dr. Russell にお願いして長時間測定の OKをもらいま した。水素減速材の中性子放出時間は 130 時間の 測定中，時々刻々変化し，時間が経過するに従っ てパルスピーク強度が増えて行きました。また， それにともなって半值幅も変化しました．エネル ギースペクトルの変化も観測されました[11]. 解 析の結果， $80 \mathrm{~kW}$ の中性子場では，オルソからパ ラへの変換は自然変換と変わらないと推測されま した。これらの結果から, J-PARCではパラ変換の 触媒を入れて，ほぼ $100 \%$ のパラ水素を利用する ことを決めました。一方，SNS では比較的中性子 特性の変化の少ない中間のパラ濃度を採用するこ とにしました。一緒に実験したにもかかわらず異 なった道を辿りました. J-PARCでは，さらに円筒 形にすることで取り出し角度による強度変化の少 ない減速材としました[12]. J-PARC と他施設との 中性子スペクトルの比較を Fig.4 に示します. J-PARC の結合型減速材は, SNS の 2MW と比較し ても強度が高く，我々が採用した結合型液体水素 減速材は，現在，最も効率の良い冷中性子減速材 です。

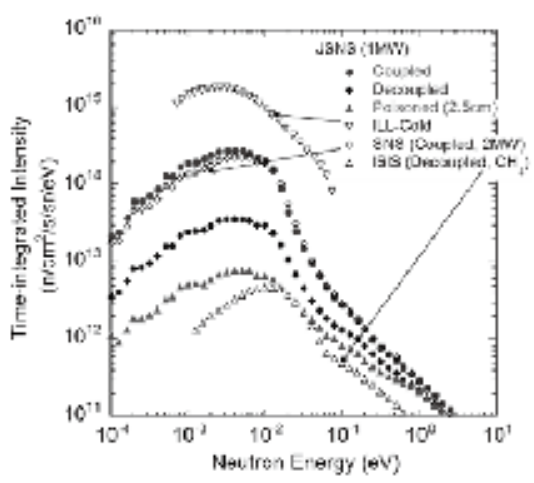

Fig. 4 Comparison of energy spectra from J-PARC moderators, a SNS moderator and the ILL cold moderator.

\section{3. パルス中性子イメージング}

中性子イメージング (ラジオグラフィー) は, 従来，白色中性子を用いて行われてきました。し かし，単なる透過強度に基ずく画像では物足りな いと感じ，パルス中性子を使って，中のものが何 かを判別することができないだろうか，というの が最初の動機でした。 パルス中性子源では，2 次 元検出器のピクセル毎に飛行時間スペクトルが得 られるので，中性子断面積に表れるブラッグエッ ジを用いて，合金を識別することを最初に考えま した[5]. 飛行時間測定ができる 2 次元検出器とし てファイバー型検出器による実験を最初に行いま
した[13].これは世界初のパルス中性子源を用い たエネルギー選別イメージングだと思っています。 Cd の下に隠れたポリエチレンの'H'の字を高エネ ルギー中性子領域で，ビニールテープの'U'の字を 冷中性子領域で一度の測定で見ることができまし た。 また, 物質による断面積の違いで物質の相違 も明らかにできました。しかし，検出効率が非常 に低かったため, 空間分解能が約 $2 \mathrm{~mm}$ と悪いが, ピクセル型の検出器を考え, 最高の計数率のもの を開発しました[14]. これを用いて本格的測定を 開始し,色々な分野へ展開することができました。

林眞琴氏から提供して頂いた，表面改質した鉄 鋼材料と熱処理したもので，透過断面積が異なる ことを見たのが, 結晶組織構造解析へと向かう新 しいステップの始まりでした. Fig.5 は干渉性散乱 が支配的な物質の中性子断面積です。低エネルギ 一側にブラッグ散乱に起因するエッジ，即ちブラ ッグエッジが現れています。この波長は図中のブ ラッグの式で分かるように結晶面間隔に対応しま す．また，その形状は結晶子サイズや結晶配向の 度合いによって変化します[15,16]. このような情 報を得るための解析コード RITS も作成されまし た[17]. エネルギーが高いところでは，共鳴断面 積が現れます。共鳴エネルギーで元素分析が, 幅 で温度測定ができます。もう一つの中性子の重要 な特性は磁気モーメントがあることで，偏極中性 子を用いて磁場通過後の偏極度を中性子波長依存 で測定することによって, 磁場分布と強度を求め ることができます $[16,18]$.

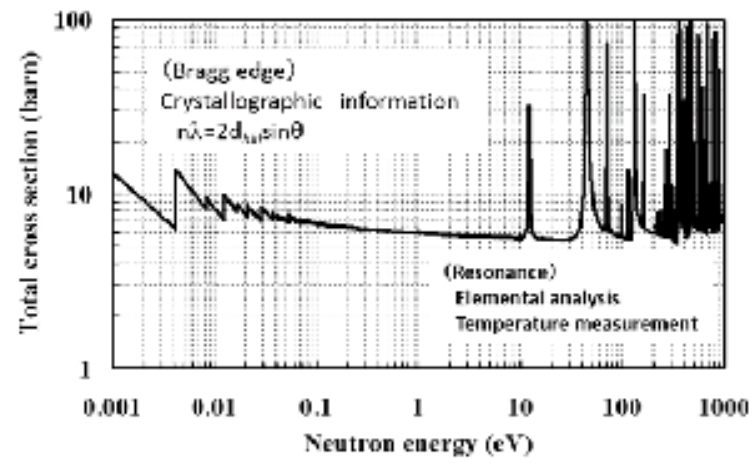

Fig. 5 Characteristics of a neutron cross section used for the pulsed neutron imaging.

以下, ブラッグエッジ解析について紹介します。 引つ張り試験中の結晶組織構造がどのように変化 するかを見るために，切欠きのある鉄板を用いて その場測定をMLF の匠で実施しました $[15,19]$.

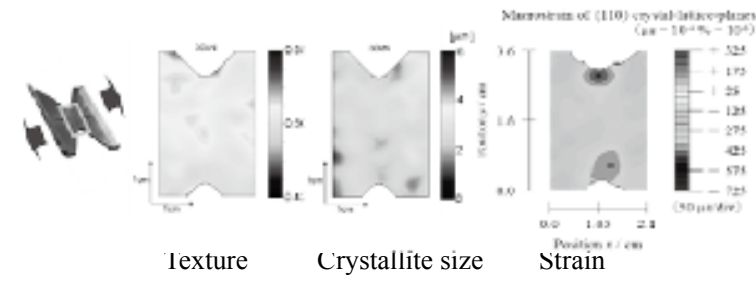

Fig. 6 Texture, crystallite size and strain during in-situ tensile test of a notched iron plate. 
Fig. 6 は負荷が $30 \mathrm{kN}$ のときの結晶配向度, 結晶子 サイズ，歪みの分布です．左にサンプルの写真と 測定部位(四角で囲んだ部分)を示してあります. 切欠きの近辺で歪みが大きくなっているのが分か ります. 負荷に応じてこれらの分布が変化し, $49 \mathrm{kN}$ 近辺で大きく変わることが観測されました.

また，焼き入れ丸棒についての測定も行いまし た。これはメーカーからの課題として始めたもの で，当初は焼き入れが入った位置を同定できます か’という課題でした. J-PARCの NOBORU で測 定した，焼き入れ部のブラッグエッジを見ている うちに, 他と比べて形に変化があることに気づき， その解析が RITS に組み込めることも分かりまし た。それが，エッジ幅解析（回折ピークの幅に相 当）です. Fig. 7 はエッジ幅（結晶面閒隔分布の 幅）の分布です．外側の白い所が焼入れ部に対応 しており，予定された焼入れ梁さと一致していま す.この幅の広がりと Vicker's 硬さの対応を見て いて，比例関係がありそうだと気づき，その対応 関係を Fig. 8 のよう求めました[20].このテーマ は，当初の目標を越えて，非破壊での硬さ測定に までつながりました。
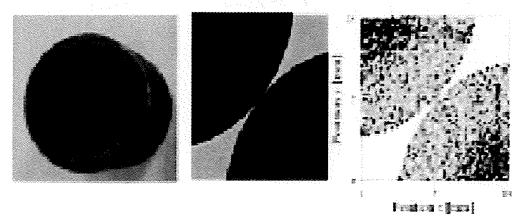

Fig. 7 Photo of a quenched iron, traditional transmission image, width of lattice plane distribution.

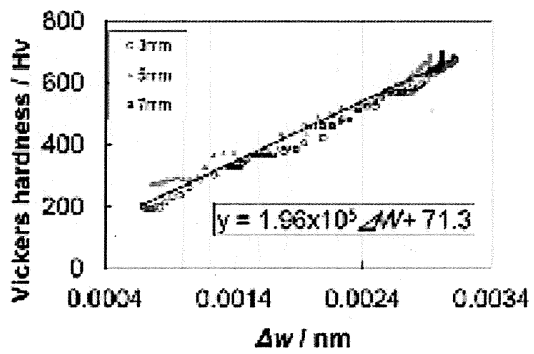

Fig. 8 Relation of Vickers hardness and lattice plane distribution, $\Delta W(\mathrm{~nm})$.

4. おわりに

超冷中性子から $\mathrm{GeV}$ 中性子まで, 広いエネルギ

一範囲に亘って中性子をテーマにした研究を続け

て来ました，冷中性子源開発では色々な減速材を 試しましたが，結合型水素冷中性子源に出会えた のは幸運でした．パルス中性子イメージングは， 当初の単純な発想を超えて, 色々な用途開けてき ています。今後の発展を期待している所です.

日本加速器中性子源協議会 JCANS（Japan Collaboration of Accelerator-driven Neutron Sources) を結成し，小型中性子源の利用を進め，産業界を 巻き込んだ活動も始めました。中性子に対する期 待が大きいものを感じています．残り何年かです が，この分野に貢献できればと思っています。
謝辞

これまで色々な研究を遂行できたのは，加美山 隆准教授, 岩佐浩克技術職員, 平賀富士夫助教に 負う所極めて大です.また, 研究室の学生, 院生, 職員には本当に支えられました，北大外の方にも 大変お世話になりました。特に, 故渡邊昇先生に は色々な局面でお世話になりました．周りの皆様 のお陰でここまで来られたと，しみじみ感じてい ます.この場を借りて,心より御礼申し上げます.

参考文献

[1] K. Inoue, N. Otomo, H. Iwasa and Y. Kiyanagi, J. Nucl. Sci. Tech., 11, 228 (1974).

[2] K. Inoue, Y. Kiyanagi, H. Iwasa and Y. Sakamoto, Nucl. Instr. Meth., 178, 459 (1980).

[3] K. Inoue, et al., Nucl. Instr. Meth., A238, 401 (1985).

[4]Y. Kiyanagi and H. Iwasa, Proc. 5th Int. Symp. Advanced Nuclear Energy Research-Neutron as Microscope Probes, 10-12 Mar 1993, Ibaraki, Japan, JAERI-M, 93-228, Vol.2, 796 (1993)

[5] H. M. Shimizu, et al., Physica B; Condensed Matter, 241-243, 172 (1998).

[6] Y. Kiyanagi, J. Korean Phys. Soc., 59, 779 (2011).

[7] A. Kimura, et al., J. Nucl. Sci. Tech., 49, 708 (2012).

[8] Y. Kiyanagi, N. Watanabe and H. Iwasa, Nucl. Instr. Meth., A312, 561 (1992).

[9] Y. Kiyanagi, M. Ooi, H. Ogawa and M. Furusaka, J. Neutron Research, 11, 3 (2003).

[10] M. Ooi, H. Ogawa, T. Kamiyama and Y. Kianagi, Nucl. Instr. Meth., A659, 61 (2011).

[11] M. Ooi, et al., Nucl. Instr. Meth., A566, 699 (2006).

[12] T. Kai, M. Harada, M. Teshigawara, N. Watanabe, Y. Kiyanagi, Y. Ikeda, Nucl. Instr. Meth., A550, 329 (2005). [13] N. Sakamoto, et al., J. Appl. Crystallogr, 36, 820 (2003).

[14] K. Mizukami, et al., Nucl. Instr. Meth., A529, 310 (2004).

[15] 鬼柳善明, 加美山隆,日本中性子科学会誌「波 紋」, 21, 174 (2011).

[16] Y Kiyanagi, $\mathrm{H}$ Sato, $\mathrm{T}$ Kamiyama and $\mathrm{T}$ Shinohara, J. Phys., Conf. Ser., 340, 012010 (2012).

[17] H. Sato, T. Kamiyama and Y. Kiyanagi, Mater. T. JIM, 52, 1294 (2011).

[18] T. Shinohara, et al., Nucl. Instr. Meth., A651, 121 (2011).

[19] K. Iwase, et al., J. App. Crystallogr., 45, 113 (2012).

[20] H. Sato, et al., Mater. T. JIM, 56, 1147 (2015). 